\title{
Growth of duckweed upon exposure to aluminum and atrazine in the laboratory conditions
}

\author{
Sự phát triển của bèo tấm khi phơi nhiếm với nhôm và atrazine trong điều kiện \\ phòng thi nghiệm
}

Research article

Thi-My-Chi Vo ${ }^{1}$, Minh-Phap Dao ${ }^{2}$, Thanh-Son Dao ${ }^{1 *}$

${ }^{1}$ Hochiminh City University of Technology, 268 Ly Thuong Kiet St., Dist. 10, Hochiminh City, Vietnam; ${ }^{2}$ Department of Natural Resources and Environment of Dong Nai Province, 520 Dong Khoi St., Bien Hoa City, Vietnam

\begin{abstract}
The trace metals and pesticides are commonly found in surface water receiving industrial and agricultural effluents. However, the potential negative effects of these compounds on aquatic ecosystems have not been deeply studied. Hence, the aim of this study is to assess the single and combined effects of aluminum (Al) and atrazine on the development and growth rate of duckweed, Lemna minor L. The single exposures were implemented with either Al or atrazine at the concentration of 5, 50 and $500 \mu \mathrm{g} \mathrm{L}^{-1}$ and a binary exposure was conducted with $50 \mu \mathrm{g} \mathrm{L}^{-1}$ of $\mathrm{Al}$ and $5 \mu \mathrm{g}$ $\mathrm{L}^{-1}$ of atrazine for two weeks. The results revealed that both $\mathrm{Al}$ and atrazine at the concentration of $500 \mu \mathrm{g} \mathrm{L}^{-1}$ strongly inhibited the development and growth rate of the duckweed. On the contrary, the mixture of Al and atrazine showed antagonistic effects on the plant. To our knowledge, this is the first report on the combined effects of these two contaminants on the duckweed. Therefore, our results could be useful for environmental managers in setting up and adjusting the safe guideline values in Vietnam for $\mathrm{Al}$ and atrazine in natural waters in term of ecological health protection.
\end{abstract}

Kim loại nặng và thuốc trù̀ sâu thường được tìm thấy trong các nguồn nuớc mặt, nơi tiếp nhận nước thải công nghiệp và nông nghiệp. Tuy nhiên, nhũng ảnh hưởng tiềm tàng mang tính tiêu cực của nhũng hợp chất này đối với hệ sinh thái thủy vực chưa được nghiên cúu đầy đủ. Do đó, mục tiêu của nghiên cứu này nhằm đánh giá nhũng ảnh hưởng riêng lẻ và kết hợp của nhôm (Al) và atrazine lên sự phát triển và tốc độ sinh trưởng của bèo tấm, Lemma minor L. Sự phơ nhiếm riêng

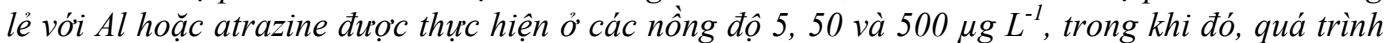
phơ nhiếm kết hợp được tiến hành với Al tại nồng độ $50 \mu \mathrm{g} \mathrm{L^{-1 }}$ và atrazine tại nồng độ $5 \mu g L^{-1}$ trong hai tuần. Kết quả cho thấy cả Al và atrazine ở nồng độ phơ nhiễm $500 \mu \mathrm{g} \mathrm{L} \mathrm{L}^{-1}$ kìm hãm mạn mẽ sư phát triển và tốc độ sinh truởng của bèo tấm. Ngược lại, sụ kết hợp Al và atrazine dẫn kết tác động triệt tiêu trên bèo tấm. Theo sư hiểu biết của chúng tôi, đây là ghi nhận đầu tiên về nhũng ảnh hưởng kết hợp của hai chất gâyy ô nhiếm này lên bèo tấm. Vì vậy, nhưng kết quả này có thể hưu ích cho các nhà quản lý môi trường tại Việt Nam trong việc thiết lập và điều chỉnh các giá trị an toàn đối vói Al và Atrazie trong môi trương nước tụ nhiên về khía cạnh bảo vệ súc khỏe sinh thái.

Keywords: Combined effects, development, growth rate, Lemma minor, toxicity.

\section{Introduction}

Over the past decades, there has been increasing concern about the occurrence of trace metals and pesticides in the water resources with high concentrations due to its serious impacts on the environment and human health [1 - 3]. Therefore, studies on the bioavailability and toxicity of these pollutants e.g. aluminum (Al) and atrazine have been conducted to understand fully about the possible hazard in aquatic environment. Aluminum is one of the natural elements, however, it is released into the environment in considerable amount by anthropogenic activities (e.g. industrial and agricultural production, mining operation) $[4,5]$. Many studies have indicated that exposures to 
$\mathrm{Al}$ at high concentrations can result in negative influences on plants, animals and especially humans. Regarding plants, toxic effects of Al are clearly identifiable through morphological and physiological symptoms [6] and primarily root-related [7]. While Dipierro et al. (2005) reported that Al inhibited root growth associated with cell division [8], some other investigations demonstrated that Al changed functions in roots [9], inhibited proton extrusion from the roots [10], decreased root respiration and uptake and use of water and nutrients, particularly calcium and phosphorus and metabolic pathway [6]. Furthermore, long term accumulation of this element in vegetables through root uptake caused potential health risks to the consumers [11]. On the other hand, atrazine, a herbicide, could be observed in freshwater bodies such as creeks, rivers, ponds, reservoirs and ground water and is classified as moderately toxic to aquatic species [12 - 14]. Hughes et al. (1988) determined the 50\% inhibition concentrations of the herbicide atrazine for Lemma gibba, Anabaenaflos-aqua, and Navicula pelliculos were 0.17, 0.23 , and $0.06 \mathrm{mg} \mathrm{L}^{-1}$, respectively [15]. Additionally, Phewnil et al. (2012) also showed that the growth rate of Lemna perpusilla significantly decreased after exposed to this chemical. The concentration of atrazine inhibiting growth by $50 \%\left(\mathrm{IC}_{50}\right)$ was $13,487 \mu \mathrm{g} \mathrm{L}^{-1}$ [16]. Solomon et al. (1996) cautioned that, when atrazine is retained in small, standing-water reservoirs or has repeated inputs into reservoirs, damage can occur in the aquatic ecosystem [17].

Chemical interactions may occur out-side the exposed organism, in which one compound influences the availability of other [18]. The combined effects of contaminants may be additive, synergistic (more than additive), or antagonistic (less than additive) than expected effects from separate exposures [19-20]. Synergistic interactions are mostly found in metal/metal mixtures due to the alteration in ion speciation outside the organism [21]. Some herbicides like atrazine can potentially react with metal ions and form complexes that may inhibit absorption in the resulting mixture, and thus reduce the toxicity of the mixture [18]. For example, atrazine has been reported to potentially interact with $\mathrm{Cd}$ ions $\left(\mathrm{Cd}^{2+}\right)$ generating anhydrous and hydrated complexes, which block the absorption process of these two compounds. The interactions between atrazine and $\mathrm{Cd}$ outside of the target organism might reduce the absorption process resulting in the antagonistic effects [22]. So far, combined effects of both heavy metals and pesticides, particularly Al and atrazine to plants from Vietnam where these contaminants are widely found have not been known deeply. Hence, in this study, we examined single and combined effects of $\mathrm{Al}$ and atrazine on the development of a certain duckweed species, Lemna minor L., in order to provide useful information for distinct environmental protection agencies and policy makers.

\section{Materials and methods}

\subsection{Materials}

The stock Al solution (Merk, Germany) at concentration of $1000 \mathrm{mg} \mathrm{L}^{-1}$ used in the experiment was aluminum standard for ICP whereas atrazine in the stock solution of $1000 \mathrm{mg} \mathrm{L}^{-1}$ were prepared by dissolving atrazine (Merk, Germany) in $\mathrm{MeOH}$ at the concentration of $1000 \mathrm{mg} \mathrm{L}^{-1}$ and both the stock Al and atrazine solution were kept at $70^{\circ} \mathrm{C}$ prior to the experiment.

The duckweed, Lemna minor L., isolated from a small pond in Dong Nai Province, was cultivated with proper density $\left(800-1600 \mathrm{~g}\right.$ wet weight $/ \mathrm{m}^{2}$, [23]) in $1000 \mathrm{~mL}$ Z8 medium (containing no aluminum) [24].

\subsection{Methods}

The duckweeds were exposed to either Al or atrazine at four distinct concentrations: 0 (control), 5, 50 and $500 \mu \mathrm{g}$ $\mathrm{L}^{-1}$. In addition, another treatment in which the duckweeds were treated with a mixture of $50 \mu \mathrm{g} \mathrm{Al} \mathrm{L} \mathrm{L}^{-1}$ and 5 $\mu \mathrm{g}$ atrazine $\mathrm{L}^{-1}$ was also conducted at the same time.

Each treatment was carried out in triplicate, in which 10 duckweed, each plant had two leaves, were cultured in a $2000 \mathrm{~mL}$ plastic cup containing $1500 \mathrm{~mL}$ Z8 medium over a period of 14 days [25]. During the experiment, the number of plants in each treatment was recorded every two days. Al and atrazine concentrations in the experiments were chosen based on Vietnam Regulation QCVN 01:2009/BYT - National technical regulation on drinking water quality. Both culturing and experimental conditions were at $27 \pm 2^{\circ} \mathrm{C}$ (daily checked with a thermometer), a photoperiod of $12 \mathrm{~h}$ light: $12 \mathrm{~h}$ dark cycle and a light intensity of around 2500 Lux.

Growth rate of duckweeds was calculated according to the equation of $\mathrm{R}=(\ln \mathrm{X} 2-\ln \mathrm{X} 1) /(\mathrm{t} 2-\mathrm{t} 1)$, where $\mathrm{X} 1$ and $\mathrm{X} 2$ are plant densities at time $\mathrm{t} 1$ and $\mathrm{t} 2$ [26]. KruskalWallis test, Sigmaplot version 12, was used for evaluating the significant difference on the number of plants and the growth rate between control, single and combined exposures.

\section{Results and discussion}

During the first 4 experimental days, there was not any statistical difference in the number of plants between control and all Al exposed treatments. However, from the sixth day of experiment, the number of plants observed in the $\mathrm{Al}$ exposed treatment at the highest concentration (500 $\mu \mathrm{g} \mathrm{L}^{-1} ; 23 \pm 1$ plants/ beaker) was statistically lower than that in the control $(32 \pm 1.4$ plants/ beaker $)$ while the number of plants in the $\mathrm{Al}$ exposed treatments at concentrations of 5 and $50 \mu \mathrm{g} \mathrm{L}^{-1}(29.6 \pm 1.4$ plants/ beaker and $30.3 \pm 2.1$ plants/ beaker, respectively) were similar with that in control (Fig.1). The trace metals toxicity usually recorded relating to the declines in photosynthetic pigment contents, particularly chlorophyll and carotenoid contents, that may result in the growth inhibition [6]. The reasons could be that the duckweed might tolerate $\mathrm{Al}$ at the applied concentration with the notable effects on neither photosynthetic pigment contents nor significant multiplication inhibition [27]. As the result during the whole course of the experiment (14 days), the growth rate of the duckweeds exposed to $\mathrm{Al}$ at concentrations of 5 and 50 $\mu \mathrm{g} \mathrm{L}^{-1}$ were $0.18( \pm 0.019)$ and $0.18( \pm 0.026)$, respective- 
ly, similar with that in the control $(0.18 \pm 0.028)$. The plants exposed to $\mathrm{Al}$ at the highest concentration had lower growth rate $(0.14 \pm 0.018)$ than that in the control (Fig. 3). This result resembles with the previous study testing the growth of duckweed (L. minor) in which plant growth was decreased when exposed to $\mathrm{Cu}$ at then concentration from $50-500 \mu \mathrm{g} \mathrm{L}^{-1}$ [28].

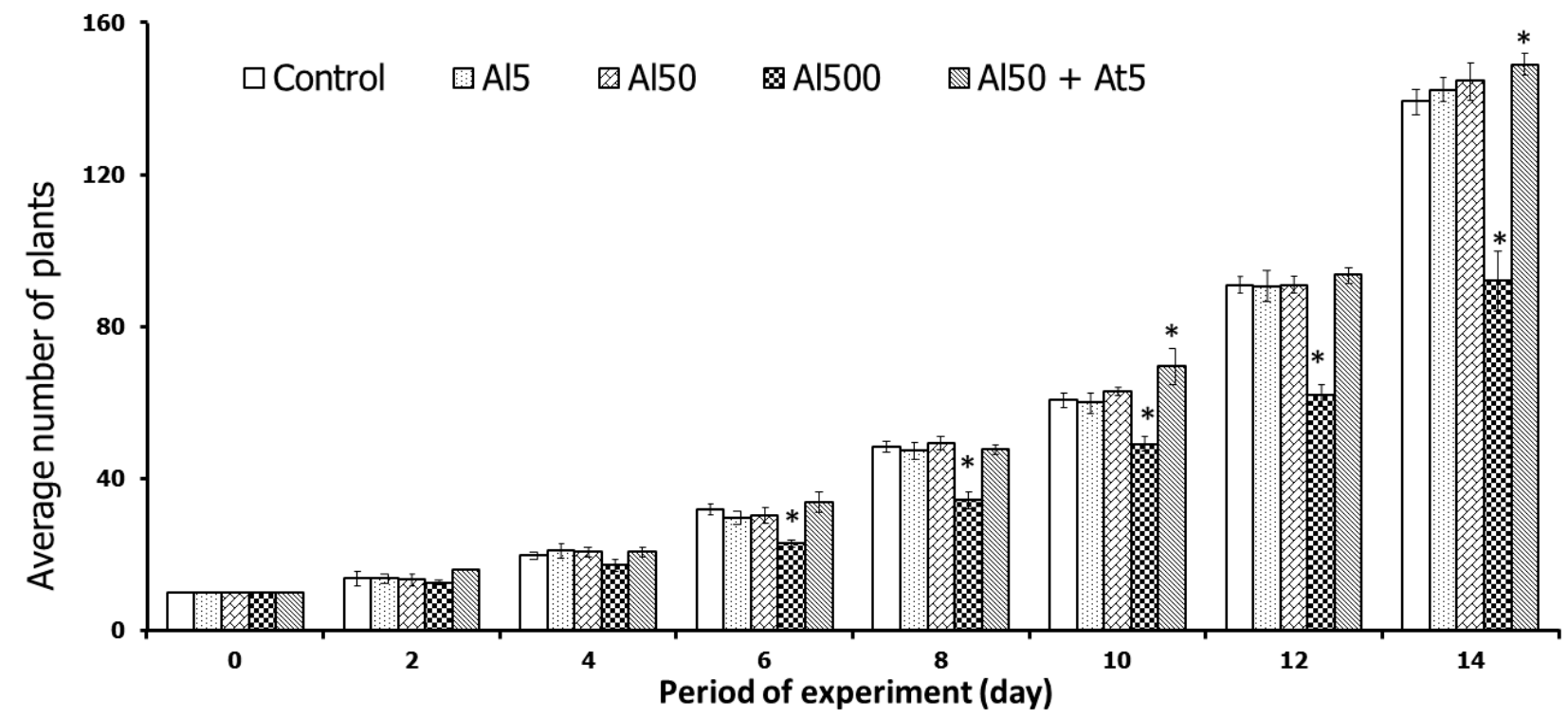

Figure 1. The development of duckweed exposed to Al and mixture of Al and atrazine. Al 5, Al 50, Al 500, plants

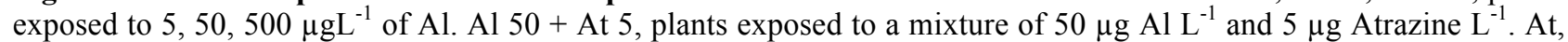
Atrazine. The asterisk $\left(^{*}\right)$ indicated the significant different between control and exposures $(\mathrm{p} \leq 0.05$; by Kruskal-Wallis test).

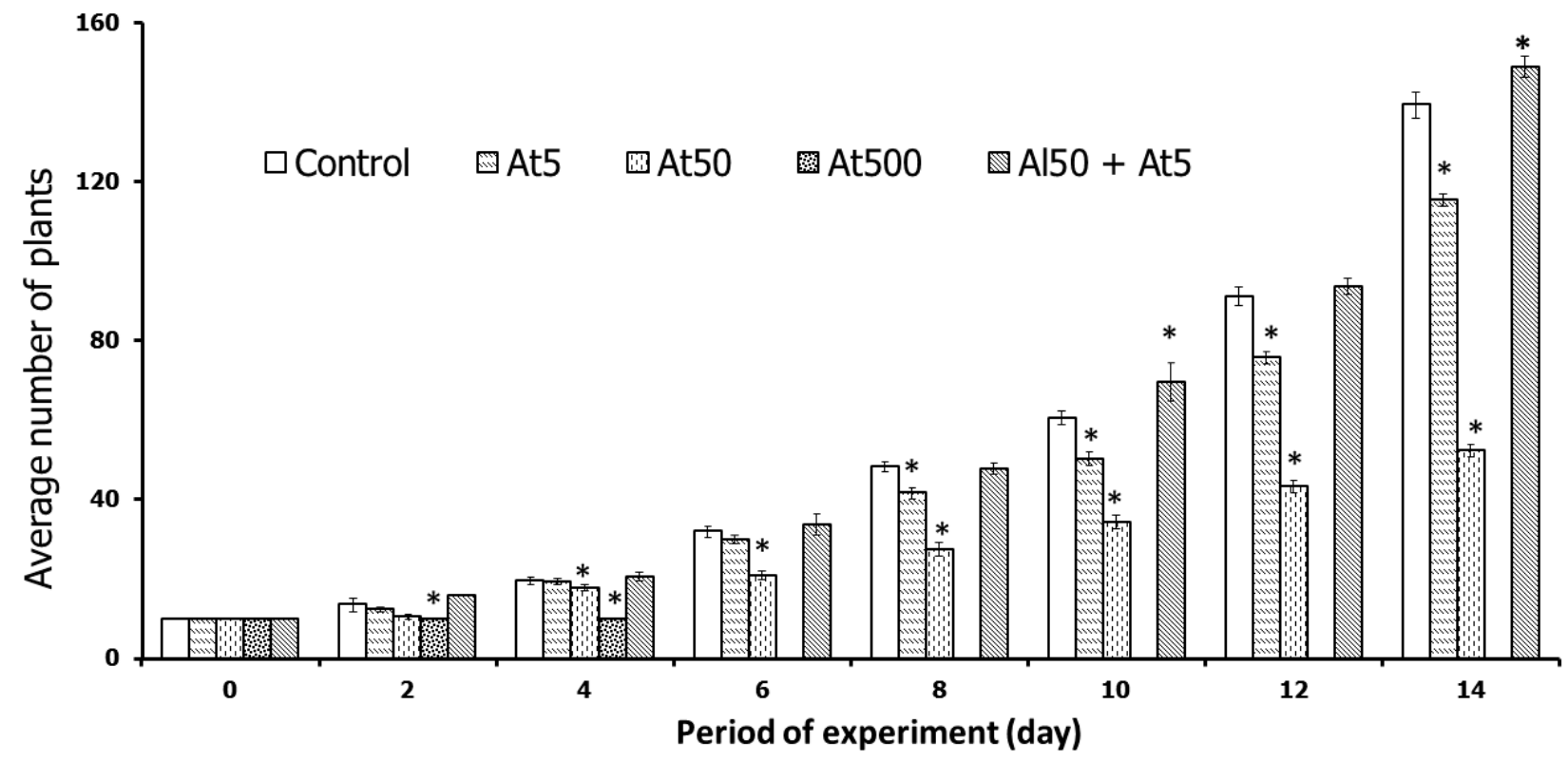

Figure 2. The development of duckweed exposed to Atrazine (At) and mixture of Al and atrazine. At 5, At 50, At

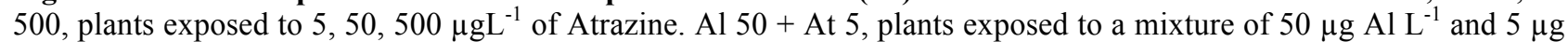
Atrazine $\mathrm{L}^{-1}$. The asterisk $(*)$ indicated the significant different between control and exposures $(\mathrm{p} \leq 0.05$; by KruskalWallis test).

On the other hand, after four days of incubation, the number of duckweeds exposed to Atrazine at the concentration of $500 \mu \mathrm{g} \mathrm{L}^{-1}$ the same as the start of the test and by the sixth day of experiment all plants in this treatment died. Moreover, the numbers of duckweeds in the treatment with lower Atrazine concentrations $(5$ and $50 \mu \mathrm{g} \mathrm{L}$ $\left.{ }^{1}\right)$ were statistically lower than the control (Fig. 2). Consequently, the plants exposed to Atrazine had lower growth rates $\left(0.16 \pm 0.026\right.$ for $5 \mu \mathrm{g}$ Atrazine $\mathrm{L}^{-1}$; and 0.11 \pm 0.036 for $50 \mu \mathrm{g}$ Atrazine $\left.\mathrm{L}^{-1}\right)$ compared to the control $(0.18 \pm 0.028$; Fig. 3$)$. Our results revealed that exposure to $5 \mu \mathrm{g}$ Atrazine $\mathrm{L}^{-1}$ already caused an inhibition in the growth of L. minor.

For each experimental concentration, effects of Atrazine on duckweed development seemed to be severer than 
effects of $\mathrm{Al}$ on duckweed development. There have been numerous studies on the effect mechanism in aquatic plants caused by Atrazine. These studies inferred that Atrazine affected plants by interfering on the electron transfer of the Photosystem II (PSII) of photosynthesis process. PSII was supramocular pigment in chloroplast, which serves to pass electron from water to plastoquinone (PQ) and releases oxygen [29-31].

The number of plants cultured in the mixture of $\mathrm{Al}$ and Atrazine were higher than those in the treatments $50 \mu \mathrm{g}$ $\mathrm{A} 1 \mathrm{~L}^{-1}$ or $5 \mu \mathrm{g}$ Atrazine $\mathrm{L}^{-1}$. Furthermore, the total number of plants exposed $\mathrm{Al}$ and Atrazine simultaneously at concentrations of $50 \mu \mathrm{g} \mathrm{L}^{-1}$ and $5 \mu \mathrm{g} \mathrm{L}^{-1}$, respectively, devel- oped as well as that in the control, even the number of plants in this treatment was statistically higher than that in the control on the tenth and last days of experiment (Figs. 1 and 2). This phenomenon can be explained as Atrazine contains five electron-donoratoms which can potentially bound with other chemicals such as $\mathrm{Cd}$ to form atrazine$\mathrm{Cd}$ complexes resulted in reducing the toxicity characteristics of the individual compound [32]. Although RodeaPalomares et al. (2010) concluded that synergism was the predominant interactions in a wide range of the effects level, the results of this studies demonstrated that the combination of $\mathrm{Al}$ and Atrazine showed antagonistic effects [33].

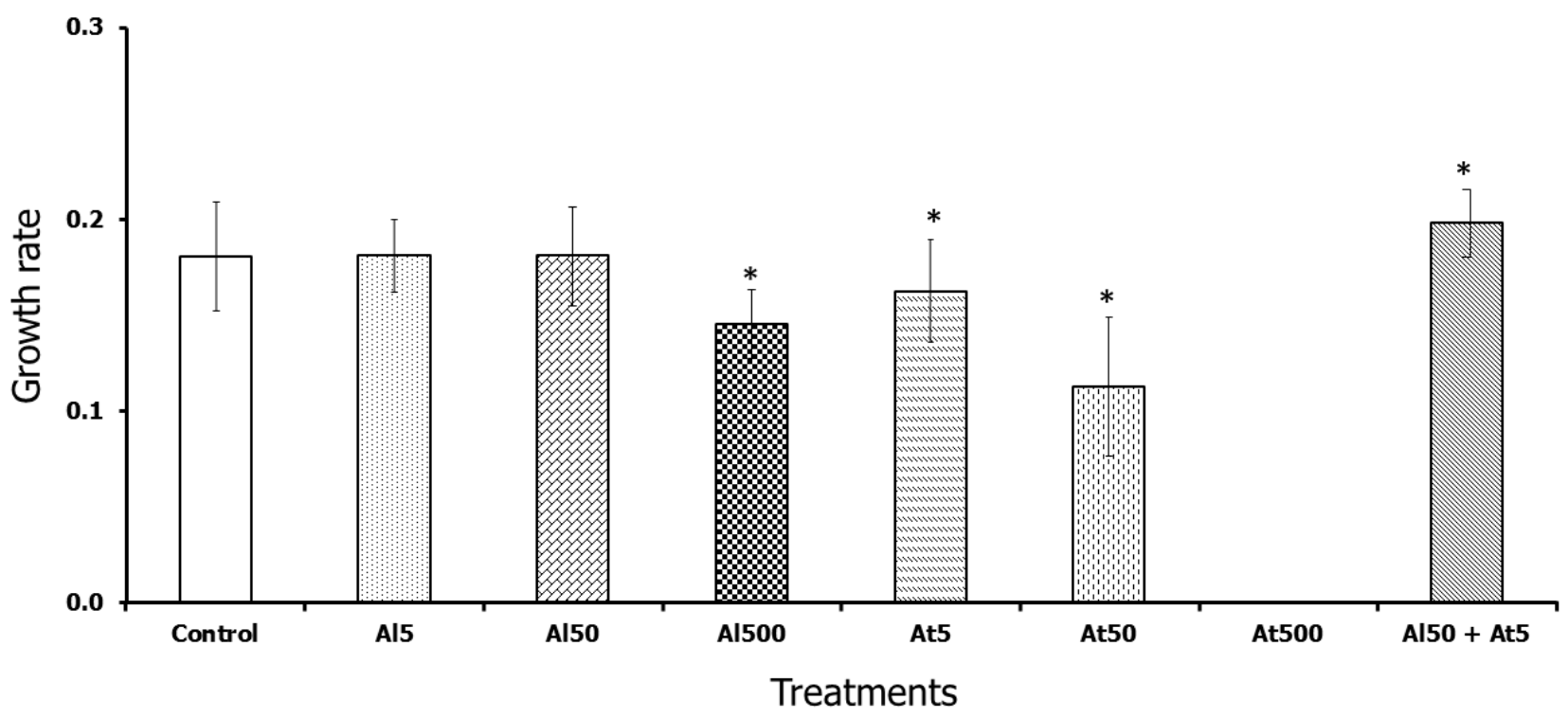

Figure 3. The growth rate of duckweed exposed to Al, Atrazine (At) and mixture of Al and atrazine. Abbreviation as in Fig. 1 and Fig 2. The asterisk $\left(^{*}\right)$ indicated the significant different between control and exposures $(\mathrm{p} \leq 0.05 ;$ by Kruskal-Wallis test).

\section{Conclusion}

The present study indicated that both $\mathrm{Al}$ (at the concentration of $500 \mu \mathrm{g} \mathrm{L}^{-1}$ ) and Atrazine (at the concentrations of 50 and $500 \mu \mathrm{g} \mathrm{L}^{-1}$ ) adversely affected on development of duckweed, L. minor. Growth rate of this plant was also inhibited by $\mathrm{Al}\left(500 \mu \mathrm{g} \mathrm{L}^{-1}\right)$ and Atrazine (from $\left.5 \mu \mathrm{g} \mathrm{L}^{-1}\right)$. Negative impact of Atrzine on duckweed was stronger than that of Al. The mixture of $\mathrm{Al}$ and Atrazine resulted in the antagonistic effects on the duckweed. Combined effects of trace metals and herbicides on plants were usually focused on soil environment [34], our results were informative and helped to get more understanding on the toxicity of trace metals and herbicides, particularly Al and Atrazine on the aquatic plants. Further investigations on the molecular interaction between $\mathrm{Al}$ and Atrazine are suggested.

Acknowledgement: The authors would like to thank Dr. Van-Son Dang, Institute of Tropical Biology, for species identification on the duckweed used in this study as Lemna minor L.

\section{References}

[1] Tchounwou, P.B., Yedjou, C.G., Patlolla, A.K., Sutton D.J. (2014). Heavy Metal Toxicity and the Environment. In: Luch A. (eds) Molecular, Clinical and Environmental Toxicology. Experientia Supplementum, Vol. 101. Springer, Basel.

[2] Baishya, K. and Sarma, H.P. (2014). Effect of agrochemicals application on accumulation of the heavy metals on soil of different land uses with respect to its nutrient status. IOSR Journal of Environmental Science, Toxicology and Food Technology, Volume 8, Issue 7 Ver. II, 46-54.

[3] Li, T.Y. and Xiong, Z.T. (2004). A novel response of wild-type duckweed (Lemna paucicostata Hegelm.) to heavy metals. Environ. Toxicol. 19 (2), 95102.

[4] Gensemer, R.W. and Playle, R.C. (1999). The bioavailability and toxicity of aluminium in aquatic environments. Crit. Rev. Environ. Sci. Technol. 29, 315450 .

[5] Shikazono, N., Zakir, H.M., Sudo, Y. (2008). Zinc 
contamination in river water and sediments at Taisyu $\mathrm{Zn}-\mathrm{Pb}$ mine area, Tsushima Island, Japan. J. Geochem. Explor. 98, 80-88.

[6] Rout, G., Samantaray, S., Das, P. (2001). Aluminium toxicity in plants: a review. Agronomie, EDP Sciences 21 (1), 3-21.

[7] Ciamporova, M. (2002). Morphological and structural responses of plant roots to aluminium at organ, tissue and cellular levels. Biology of Plants 45: 161171.

[8] Dipierro, N., Mondelli, D., Paciolla, C., Brunetti, G., and Dipierro, S. (2005). Changes in the ascorbate system in the response of pumpkin (Cucurbita pepo L.) roots to aluminium stress. Journal of Plant Physiology 162: 529-536.

[9] Van Oene, H. (1998). A mechanistic model for the inhibiting effects of aluminum on the uptake of cations. Zeitschrift fur Pflanzenphysiologie 161, 661670

[10] Matsumoto, H. (1988). Inhibition of proton transport activity of microsomal membrane vesicles of barley roots by aluminium. Soil Science and Plant Nutrition 34, 499-506.

[11] Khan, S., Cao, Q., Zheng, Y. M., Huang, Y. Z., Zhu, Y. G. (2008). Health risks of heavy metals in contaminated soils and food crops irrigated with wastewater in Beijing, China. Environmental Pollution 152, 686-692.

[12] Battaglin, W.A., Thurman, E.M., Kalkhoff, S.J., Porter, S.D. (2003). Herbicides and transformation products in surface waters of the Midwestern United States. J. Am. Water Res. Assoc. 39, 743-756.

[13] Battaglin, W.A., Rice, C.K., Foazio, M.J., Salmons, S., Barry, R.X. (2008). The occurrence of glyphosate, atrazine, and other pesticides in vernal pools and adjacent streams in Washington, DC, Maryland, Iowa and Wyoming 2005-2006. Environ. Monit. Assoc.155, 281-307.

[14] Scrubner, E.A., Thurman, E.M., Goolsby, D.A., Meyer, M.T., Battaglin, W.A., Kolpin, D.W. (2005). Summary of Significant Results from Studies of Triazine Herbicides and Their Degradation Products in Surface Water, Ground Water, and Precipitation in the Midwestern United States During the 1990s. U.S. Geological Survey Scientific Investigations Report, 2005-5094.

[15] Hughes, J.S., Alexander, M.M., and Balu, K. (1988). An evaluation of appropriate expressions of toxicity in aquatic plant bioassays as demonstrated by the effects of atrazine on algae and duckweed. Amer. Soc. Testing \& Materials. STP 921, 531-547.

[16] Phewnil, O.A., Tungkananurak, N., Panichsakpatana, S., Pitiyont, B. (2012). Phytotoxicity of Atrazine Herbicide to Fresh Water Macrophyte Duckweed (Lemna perpusilla Torr.) in Thailand. Environment and Natural Resources Journal, 10(1), 16-27.

[17] Solomon, K.R., Baker, D.B., Richards, R.P., Dixon,
K.R., Klaine, S.J., La Point, T.W., Kendal, R.J., Weisskoff, C.P., Giddings, J.M., Giesy, J.P., Hall, Jr.L.W., Williams, W.M. (1996). Ecologycal risk assesment of atrazine in N. American surface water, Environ Toxicol Chem 15, 31-76.

[18] Uwizeyimana, H., Wang, M., Chen, W., Khan, K. (2017). The ecotoxic effects of pesticide and heavy metal mixtures towards earthworms in soil. Environmental Toxicology and Pharmacology 55, 20-29.

[19] Pape-Lindstrom, P.A. and Lydy, M.J. (1997). Synergistic toxicity of atrazine and organophosphate insecticides contravenes the response addition mixture model. Environ Toxicol Chem 16, 2415-2420.

[20] Shen, G.Q., Lu, Y.T., Hong, J.B. (2006). Combined effect of heavy metals and polycyclic aromatic hydrocarbons on urease activity in soil. Ecotoxicol Environ Saf 63, 474-480.

[21] Binderup, M.-L., Dalgaard, M., Dragsted, L.O., Hossaini, A., Ladefoged, O., Lam, H.R., Larsen, J.C., Madsen, C., Meyer, O.A., Rasmussen, E.S., Reffstrup, T. K., Søborg, I., Vinggaard, A. M., Østergård, G. (2003). Combined Actions and Interactions of Chemicals in Mixtures: The Toxicological Effects of Exposure to Mixtures of Industrial and Environmental Chemicals.

[22] Wang, J.H., Zhu, L.S., Meng, Y., Wang, J., Xie, H., Zhang, Q.M. (2012). The combined stress eff ects of atrazine and cadmium on the earthworm Eisenia fetida . Environ. Toxicol. Chem. 31 (9), 2035 -2040.

[23] DeBusk, T.A., Ryther, J.H. (1981). Effects of seasonality and plant density on the productivity of some freshwater macrophytes. Aquat. Bot. 10:133142 .

[24] Kotai, J. (1972). Instructions for preparation on modified nutrient solution Z8 for algae. Norwegian Institute for Water Research, Oslo B-11/69, 1-5.

[25] Khellaf, N. and Zerdaoui, M. (2009). Growth response of the duckweed lemna minor to heavy metal pollution, 161- 166 .

[26] Lobban, C.S., Chapman, D.J., Kremer, B.P. (1988), Experimental phycology - a laboratory mannual. Cambridge University Press., 71-72.

[27] Radic, S., Babic, M., Skobic, D., Roje, V., PevalekKozlina, B. (2009). Ecotoxicological effects of aluminum and zinc on growth and antioxidants in Lemna minor L. Ecotoxicology and Environmental safety.

[28] Vu, N., Trinh, H.P., Nguyen, T.T.T., Ho, D.C., Dao, T.D., 2017. Development of duckweed, Lemna minor L., exposed to copper and chromium in the laboratory conditions. Article of Science and technology Development 3(1), 47-53. .

[29] Giardi, M.T., Koblízek, M., Masojídek, J. (2001). Photosystem II-based biosensors for the detection of pollutants. Biosensors and Bioelectronics 16(9-12), 1027-1033.

[30] Bell, A.M. and Duke, N.C. (2005). Effects of Photo- 
system II inhibiting herbicides on Mangroves preliminary toxicology trials. Marine Pollution Bulletin 51(1-4), 297-307.

[31] Graymore, M., Stagnitti, F., Allinson, G. (2001). Impacts of atrazine in aquatic ecosystem. Environment International 26, 483-495.

[32] Meng, Z. and Carper, W.R. (2000). Effects of hydration on the molecular structure of metal ion- atrazine dimer complexes: a MOPAC (PM3) study. J. Mol. Struct. THEOCHEM 531, 89-98.
[33] Rodea- Palomares, I., Petre, A.L., Boltes, K., Legans, F., Perigón-Melón, J.A., Rosal, R., FernándezPiñas, F. (2010). Application of the combination index (CI)-isobologram equation to study the toxicological interactions of lipid regulators in two aquatic bioluminescent organisms. Water Res. 44, 427-438.

[34] Skiba, E., Kobylecka, J., Wolf, W.M. (2017). Influence of 2,4-D and MCPA herbicides on uptake and translocation of heavy metals in wheat (Triticum aestivum L.). Environmental Pollution 220, 882-890. 